Keywords: Sludge, Quencher, $D W P F$

Retention: Permanent

\title{
Characterization of DWPF Melter Off-Gas Quencher Sample
}

J.D. Newell

November 14, 2011

Savannah River National Laboratory Savannah River Nuclear Solutions, LLC Aiken, SC 29808

Prepared for the U.S. Department of Energy under contract number DE-AC09-08SR22470. 
SRNL-STI-2011-00520

Revision 0

\section{DISCLAIMER}

This work was prepared under an agreement with and funded by the U.S. Government. Neither the U.S. Government or its employees, nor any of its contractors, subcontractors or their employees, makes any express or implied:

1. warranty or assumes any legal liability for the accuracy, completeness, or for the use or results of such use of any information, product, or process disclosed; or

2. representation that such use or results of such use would not infringe privately owned rights; or

3. endorsement or recommendation of any specifically identified commercial product, process, or service.

Any views and opinions of authors expressed in this work do not necessarily state or reflect those of the United States Government, or its contractors, or subcontractors.

\section{Printed in the United States of America \\ Prepared for \\ U.S. Department of Energy}




\section{REVIEWS AND APPROVALS}

AUTHORS:

J.D. Newell, Process Technology Programs

Date

TECHNICAL REVIEW:

M.E. Stone, Process Technology Programs

Date

APPROVAL:

C.C. Herman, Manager

Date

Process Technology Programs

S.L. Marra, Manager

Date

Environmental \& Chemical Process Technology Research Programs

J.E. Occhipinti, Manager

Date

Waste Solidification Engineering 


\section{ACKNOWLEDGEMENTS}

The contributions of the following people are appreciated: Chris Bannochie provided assistance with data regression, Damon Click, Rita Sullivan, Monika Jenkins, and Dee Wheeler performed the analytical preparations and Holly Hall for sample disposition. 
SRNL-STI-2011-00520

Revision 0

\section{EXECUTIVE SUMMARY}

This report details the results from the characterization of the quencher off-gas deposit, as received from the Defense Waste Processing Facility (DWPF). DWPF requested, through a technical assistance request [1], characterization of the melter off-gas deposits by $\mathrm{x}$-ray diffraction (XRD), scanning electron microscopy (SEM), and chemical analysis.

Based on the analytical results obtained from the quencher sample, the following conclusions can be made:

- XRD data indicates the sample crystalline structures composed of trevorite, hematite, quartz, and ruthenium oxide.

- The off-gas quencher deposit is compositionally similar to mercury-enriched, fritdeficient Sludge Batch 6 (SB6) melter feed.

- Morphologically, the deposit sample is not similar to previous samples. Previous samples had clear indication of the presence of frit, which is lacking in the current samples. In addition, observable rod-like fibers can be seen in the SEM micrographs. The source of these fibers is currently unknown.

- Gamma scans detected emitters Co-60, Cs-137, Eu-154, and Am-234. Of these Cs-137 was in the highest concentration.

- Water leach testing indicated soluble sodium, boron, and sulfur in the quencher sample, with $12 \%$ of the quencher sample being water soluble.

Three possible scenarios to explain the sludge rich/ frit deficient nature of the quencher deposit were identified:

1. Sludge being selectively entrained in the off-gas. As a result of this selectivity, the deposit forming in the quencher is lacking in frit, which can be easily seen in the SEM analyses. This scenario is considered unlikely, as this type of separation has not been seen before, even with non-bubbled operations. While it is understandable that bubbler use will increase the amount of melter feed carryover, it would not explain the separation of sludge from the melter feed.

2. The frit in the quencher deposit is being selectively leached after depositing. The low $\mathrm{pH}$ of the recirculated off-gas condensate is dissolving the frit fraction of the melter feed. This scenario is also considered unlikely, as silica dissolution in glass occurs at higher $\mathrm{pH}$ rather than lower[7]. As the $\mathrm{pH}$ of the quencher water is approximately $\mathrm{pH}=2$, there would be little dissolution of the frit. It was considered more probable that the sludge would leach from the deposit than the frit.

3. The third scenario identified is that the quencher deposit is a result of particulate that has accumulated in the Offgas Condensate Tank (OGCT) and has separated into frit and sludge fractions as the frit settles to the bottom of the OGCT and the sludge particles suspend in the condensate. Sludge particles are entrained in the condensate as it recycles through the quencher and deposits below the melter spout jet. Comparison of the 
compositional analyses of the quencher and MFT samples reveals the possibility that the quencher deposits are the sludge component of the melter feed.

A high concentration of mercury was found in the quencher deposit (2.35 wt\%). The presence of mercury in the quencher is likely attributed to increasing the allowable mercury concentration sent to the melter.

SEM analysis of the quencher sample showed the presence of rod-like fibers. These fibers range from a couple of microns in diameter to 50 microns and lengths approaching $1 \mathrm{~mm}$. The fiber structure appears to be composed of an inner rod made mostly of silica with a coating that would be consistent with melter feed composition. In order to determine that the fibers are not the result of refractory collecting in the off-gas, DWPF provided Zircar and Kaowool refractory samples for SEM analysis. The analysis showed these samples to be orders of magnitude smaller in diameter than the fibers seen in the quencher sample. In addition, review of work performed by Jantzen in 1990 [6] showed fiber accumulation in the quencher, although smaller in diameter. It is postulated that the fibers seen are the result of strands of glass that have been ejected from the melt pool (due to bubbler operations) and collected in the off-gas.

In order to confirm the deposits are a result of feed in the OGCT, SRNL recommends DWPF Engineering sample the OGCT for chemical and physical analyses. Confirmation of feed in the condensate would indicate a need for evaluating methods to prevent melter feed from reaching the quencher (i.e. filtration). Samples should be taken from the top and bottom of the OGCT before and after agitation.

In order to decrease the agglomeration of material in the quencher, the following recommendations are considered: 1. OGCT pH adjustment, 2. Flocculant addition to the OGCT, 3. OGCT cleaning, 4. Addition of a steam or water jet inside the quencher, and 5. Slope angle adjustment of the quencher.

1. Currently, the OGCT $\mathrm{pH}$ is $\sim 2$. Lowering the $\mathrm{pH}$ of a mixture allows for more of the suspended particles to dissolve. In order to dissolve the suspended particles, the resulting acid concentrations (nitric, for example) may need to be as high as 6-8 molar. The amount of acid that would be needed would make this an impractical recommendation.

2. Flocculation is a process used to increase the efficiency of settling and clarification of a suspension. This is achieved as the flocculant forms bridges between suspended particles and aids in particle aggregation. While the use of a flocculant would benefit a motionless tank, the OGCT is not quiescent. As such, it is not expected that using a flocculating agent would improve the settling rate of suspended sludge particles sufficiently to prevent suspension of the particles. In addition, forcing the particles to settle could result in accumulated deposits in the tank that are difficult to suspend. Furthermore, the flocculating agent could potentially make the accumulation of solids in the quencher more severe.

3. Quencher operation over time results in particulate accumulation of any entrained solids from the off-gas system in the OGCT. Periodic cleaning of the OGCT would not result in cleaner recirculated water and slower rate of deposition in the quencher, as suspended solids are removed during frequent liquid fraction transfers of the OGCT. Cleaning the settled solids will have little or no impact on the amount of material suspended in the tank. The accumulated solids settled on the bottom of the OGCT are not likely to be contributing to the quencher deposits. 
4. The deposit recently observed in the quencher was in a position just below the quencher nozzle. The addition of a steam or water jet inside the quencher below the nozzle could be used to dislodge the deposit as it forms. Visual observation by DWPF personnel of the deposit during sample collection showed it to be a friable material; however, this may not be consistent with future sludge batches.

5. Currently, the quencher is positioned so as to slope downward at an angle of 20 degrees from horizontal. Increasing the downward slope of the quencher, even to 90 degrees downward from horizontal, could help with controlling the deposition of material. 


\section{TABLE OF CONTENTS}

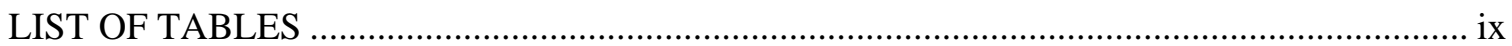

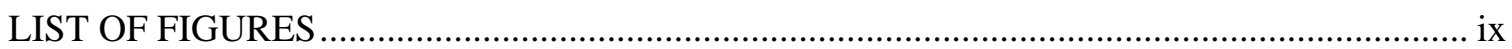

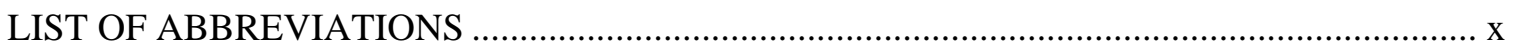

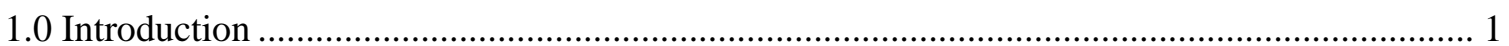

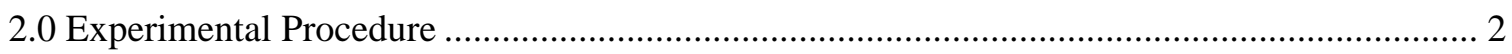

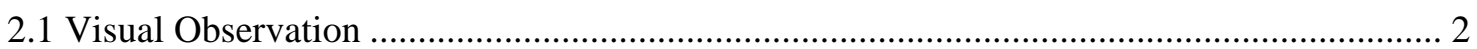

2.2 Physical Characterization of the Off-gas Sample ............................................................... 2

2.3 Chemical Composition of the Quencher Sample................................................................ 2

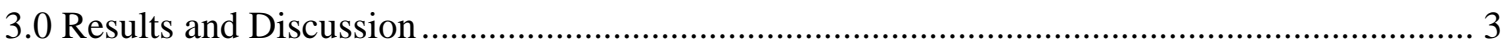

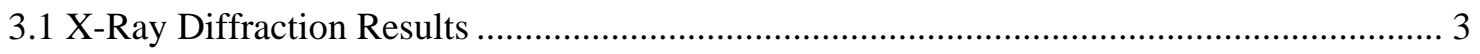

3.2 Scanning Electron Microscopy Analysis ….................................................................. 3

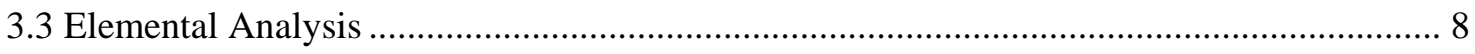

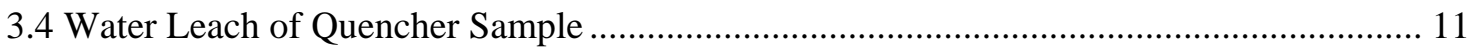

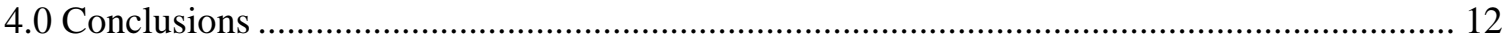

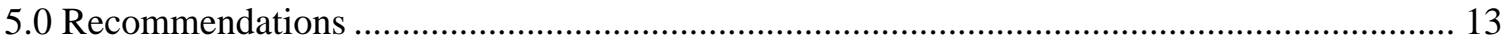

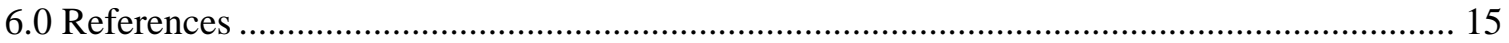




\section{LIST OF TABLES}

Table 1: ICP-AES Data for Quencher Sample (Total Solids wt\%).............................................. 9

Table 2: Comparison of SB6 Melter Feed Tank with the Quencher Sample (Total Solids wt\%). 10

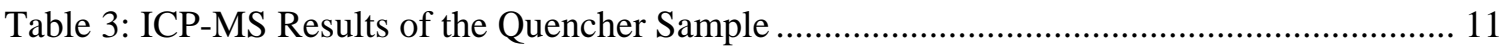

Table 4: Radionuclide Results of the Quencher Sample ............................................................... 11

Table 5: Weight Percent of Elements Dissolved in Water from the Quencher Sample ................. 12

\section{LIST OF FIGURES}

Figure 1: Depiction of the Off-gas Quencher...................................................................... 1

Figure 2. XRD Diffraction Pattern for the Quencher Sample .......................................................... 3

Figure 3: SEM Micrograph of Sample Taken from the Quencher Nozzle in 1990 showing Rod-

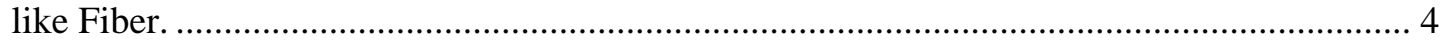

Figure 4: SEM Raster Scan of Bulk Quencher Sample............................................................. 5

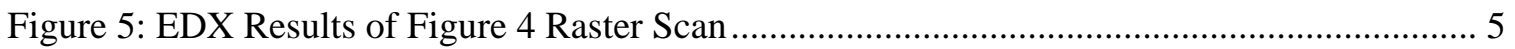

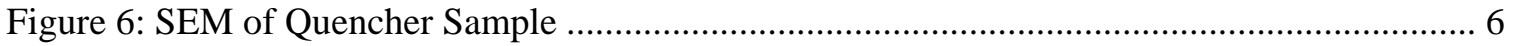

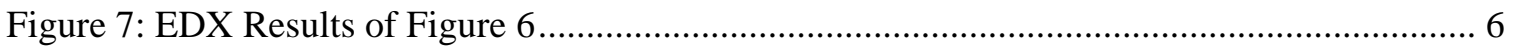

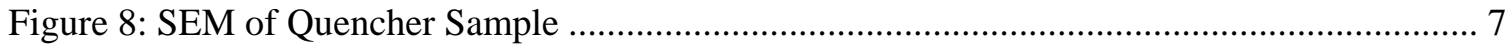

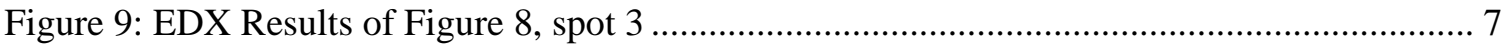

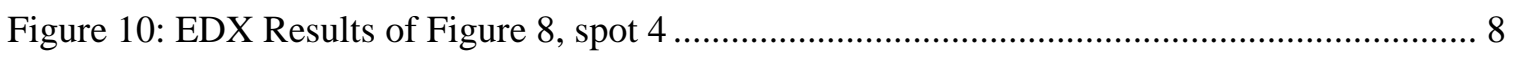

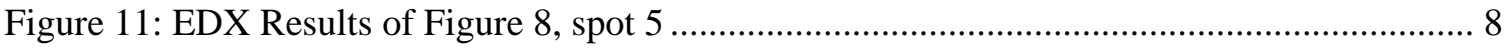




\section{LIST OF ABBREVIATIONS}

$\begin{array}{ll}\text { ACTL } & \text { Aiken County Technology Laboratory } \\ \text { AD } & \text { Analytical Development } \\ \text { CV AA } & \text { Cold Vapor Atomic Absorption } \\ \text { DWPF } & \text { Defense Waste Processing Facility } \\ \text { EDX } & \text { Energy Dispersive X-ray } \\ \text { ICP-MS } & \text { Ion Coupled Plasma - Mass Spectrometry } \\ \text { ICP-ES } & \text { Ion Coupled Plasma - Emission Spectrometry } \\ \text { NA } & \text { Not Available } \\ \text { OGCT } & \text { Off Gas Condensate Tank } \\ \text { POG } & \text { Primary Off Gas } \\ \text { PSAL } & \text { Process Science Analytical Laboratory } \\ \text { RSD } & \text { Relative Standard Deviation } \\ \text { SAS } & \text { Steam Atomized Scrubber } \\ \text { SB } & \text { Sludge Batch } \\ \text { SEM } & \text { Scanning Electron Microscopy } \\ \text { SRNL } & \text { Savannah River National Laboratory } \\ \text { SRR } & \text { Savannah River Remediation } \\ \text { TAR } & \text { Technical Assistance Request } \\ \text { XRD } & \text { X-Ray Diffraction }\end{array}$




\subsection{Introduction}

The Savannah River National Laboratory (SRNL) recently received a deposit sample from the Melter Primary Off Gas System (POG) of the Defense Waste Processing Facility (DWPF). This sample was composed of material that had been collected while the quencher was in operation January 27, 2011 through March 31, 2011. DWPF requested, through a technical assistance request [1], characterization of the melter off-gas deposits by x-ray diffraction (XRD), scanning electron microscopy (SEM), and chemical analysis.

The purpose of the Melter Off-Gas System is to reduce the amount of radioactive particles and mercury in the gases vented to the atmosphere [2]. Gases emitted from the melter pass through the primary film cooler, quencher, Off-Gas Condensate Tank (OGCT), Steam Atomized Scrubbers (SAS), a condenser, a high efficiency mist eliminator, and a high efficiency particulate air filter, before being vented to the Process Vessel Vent System.

The film coolers cool the gases leaving the melter vapor space from $\sim 750^{\circ} \mathrm{C}$ to $\sim 375^{\circ} \mathrm{C}$, by introducing air and steam to the flow. In the next step, the quencher cools the gas to about $60^{\circ} \mathrm{C}$ by bringing the condensate from the OGCT in contact with the effluent (Figure 1). Most of the steam in the effluent is then condensed and the melter vapor space pressure is reduced. The purpose of the OGCT is to collect and store the condensate formed during the melter operation. Condensate from the OGCT is circulated to the SAS and atomized with steam. This atomized condensate is mixed with the off-gas to wet and join the particulate which is then removed in the cyclone. The next stage incorporates a chilled water condenser which separates the vapors and elemental mercury from the off-gas steam.

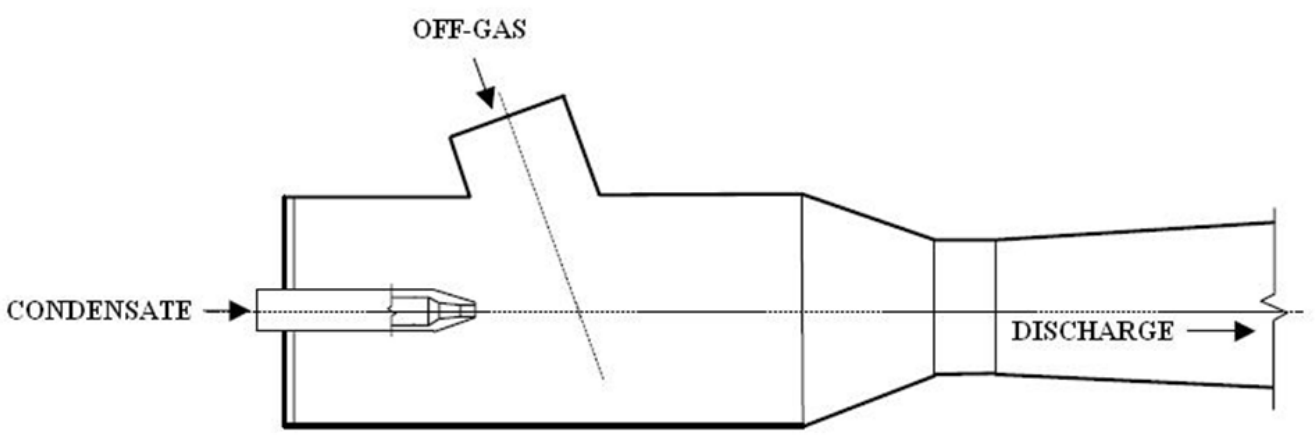

Figure 1: Depiction of the Off-gas Quencher

Primary off-gas deposit samples from the DWPF melter have previously been analyzed [3]. In 2003, samples from just past the film cooler, from the inlet of the quencher and inside the quencher were analyzed at SRNL. It was determined that the samples were a mixture of sludge and glass frit. The major component was $\mathrm{Si}$ along with $\mathrm{Fe}$, Al, and other elements in the radioactive waste being processed. The deposits analyzed also contained U-235 fission products and actinide elements. Prior to that, deposits in the off-gas system in the DWPF nonradioactive half scale melter and the one-tenth scale integrated DWPF melter system were analyzed and determined to be mixtures of alkali rich chlorides, sulfates, borates, and fluorides entrained with iron oxides, spinels and frit particles formed by vapor-phase transport and condensation [4]. Additional work was performed in 2007 in which researchers similarly found the deposits to be a combination of sludge and frit particles [5]. 
SRNL-STI-2011-00520

Revision 0

\subsection{Experimental Procedure}

\subsection{Visual Observation}

The sample received by SRNL had been taken from the inlet of the quencher. The quencher sample was black with agglomerated particles. The previous report described the quencher sample as having the "appearance of crushed chocolate cookies" [5]. This description is consistent with the visual observation of the current sample.

\subsection{Physical Characterization of the Off-gas Sample}

The quencher sample was submitted to Analytical Development (AD) for XRD and SEM characterization. XRD analysis provides information about the crystalline forms present in the sample, while SEM provides microscopic pictures and qualitative elemental analysis using energy dispersive X-ray analysis (EDX).

\subsection{Chemical Composition of the Quencher Sample}

Small amounts of each sample were dissolved using the aqua regia digestion and peroxide fusion techniques. Both of these methods are routine analytical methods used by AD for dissolving radioactive samples. For the aqua regia digestions, a known amount of sample $(\sim 0.25$ grams) was dissolved in $3 \mathrm{~mL}$ of concentrated nitric acid and $9 \mathrm{~mL}$ of concentrated hydrochloric acid in a sealed vessel for 2 hours in a $95^{\circ} \mathrm{C}$ oven. A small amount of fine black solids remained after dissolution. After the sample was cooled, it was diluted to a known volume (100 mL). A sealed vessel was used to ensure that any elements volatized during the process, such as mercury, were retained in the solution during the dissolution. A standard glass was also dissolved and analyzed with the samples to ensure the dissolutions were performed correctly and the analyses were accurate. With all dissolutions, a blank was also included with all of the steps followed in the procedure except for the addition of a sample.

The peroxide fusion digestion provides a check for the results from the aqua regia analysis as well as allows for the elements that the aqua regia analysis does not digest well, such as aluminum and silicon, to be obtained. For the peroxide fusion method, the sample was fused in a zirconium crucible with a mixture of sodium peroxide and sodium hydroxide for 10 minutes in a $675^{\circ} \mathrm{C}$ oven. The sample was briefly cooled and then water was added until the melt at the bottom of the crucible dissolved. A small amount of nitric acid $(25 \mathrm{~mL})$ was added to help dissolution and the complete solution was diluted with water to exactly $250 \mathrm{~mL}$. A standard glass and blank were also performed using the peroxide fusion method. Duplicate samples of each off-gas sample were dissolved by this method.

About $10-15 \mathrm{~mL}$ of the prepared solutions were removed from the Shielded Cells and submitted to $\mathrm{AD}$ for analysis. Aqua regia samples were analyzed using inductively coupled plasma(atomic) emission spectroscopy (ICP-ES), inductively coupled plasma- mass spectroscopy (ICPMS), and cold vapor atomic absorption spectroscopy (CV AA) for mercury. Peroxide fusion samples were submitted for ICP-ES and also for a gamma scan analysis to measure the major gamma emitters.

A water leach of the quencher sample was performed. The purpose of the water leach was to determine the water soluble compounds in the samples. A known amount of sample ( $1 \mathrm{gram})$ was added to a known amount of water $(\sim 100 \mathrm{~mL})$ and allowed to sit, with intermittent shaking for approximately 3.5 days. The resulting solution was filtered through a 0.45 micron filter attached to a syringe. Samples were then submitted for ICP-ES and Hg analysis. 


\subsection{Results and Discussion}

\subsection{X-Ray Diffraction Results}

One sample of the POG quencher deposit was submitted for XRD analysis. The result of the XRD analysis is shown in Figure 2 which shows the presence of crystalline compounds trevorite, hematite, quartz, and ruthenium oxide. These results are consistent with previous XRD analyses of quencher deposits $[5,6]$.

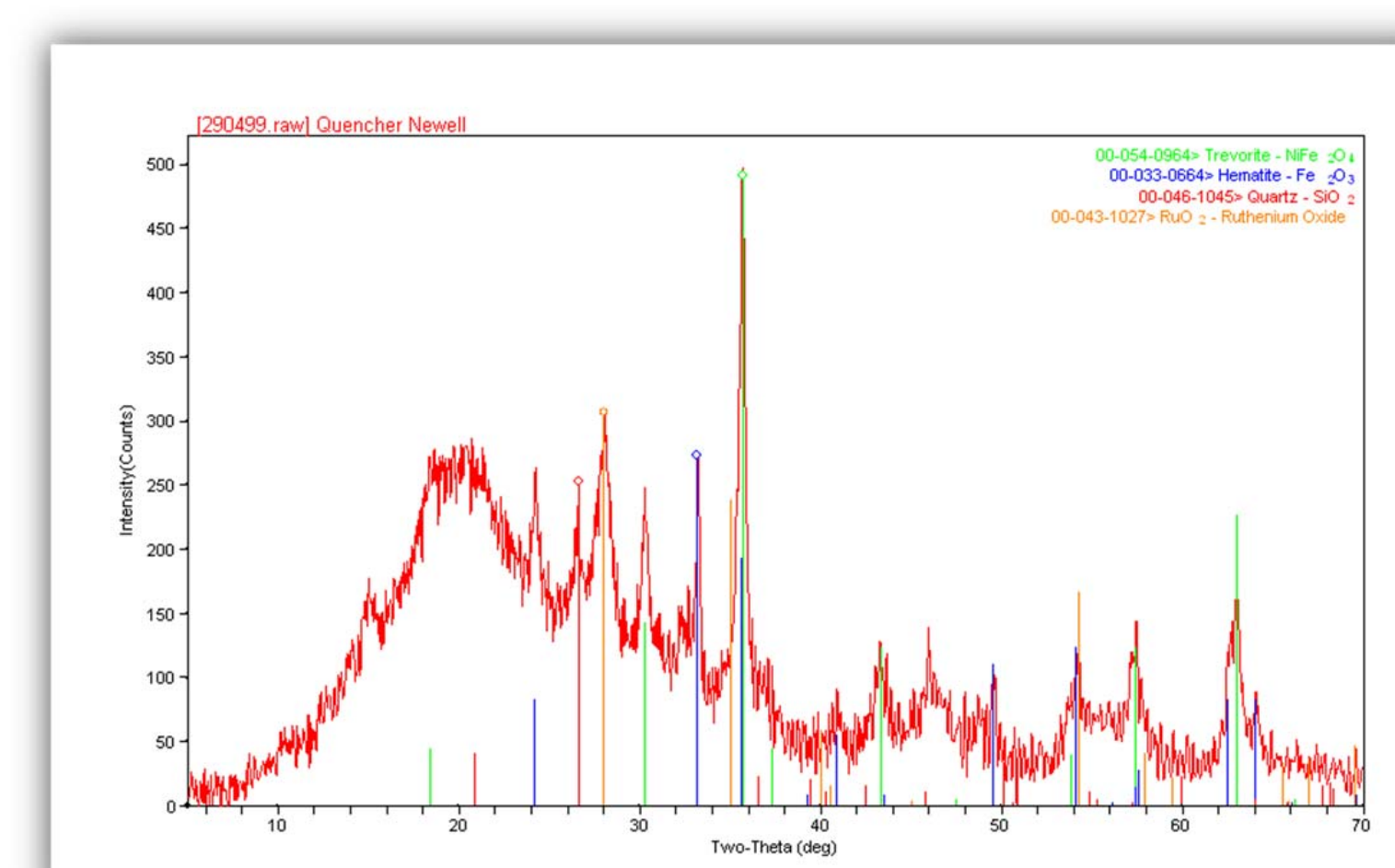

Figure 2. XRD Diffraction Pattern for the Quencher Sample

\subsection{Scanning Electron Microscopy Analysis}

A small amount of the quencher sample was submitted for SEM and EDX analyses. EDX was used to qualitatively identify the chemical composition of the materials present in the sample. Figure 4 is an EDX in which the electron beam is rastered over a large area of the sample in order to determine its chemical composition. The results of the scan, found in Figure 5, show the presence of aluminum, iron, silicon, sulfur, thorium, uranium, magnesium, manganese, and nickel. Other EDX scans indicated the presence of mercury, Figure 6 and Figure 7.

Although these samples are chemically similar to previous EDX results [5], morphologically they are very different. Previous samples showed a clear indication of the presence of frit, e.g. sharp shard-like particles. This current sample shows a more beaded material. Compositionally, these beads appear to be mostly similar to sludge with occasional mercury beads (Figure 6 through Figure 9).

Obvious in the micrographs is the appearance of rod-like fibers. These fibers range from a couple of microns in diameter to 50 microns and lengths approaching $1 \mathrm{~mm}$. The source of these fibers is currently unknown. The fiber structure appears to be composed of an inner rod made mostly of 
silica (Figure 11) with a coating that would be consistent with melter feed composition (Figure 10). In order to determine that the fibers are not the result of refractory collecting in the off-gas, DWPF provided Zircar and Kaowool refractory samples for SEM analysis. The analysis showed these samples to be orders of magnitude smaller in diameter than the fibers seen in the quencher sample. In addition, review of work performed by Jantzen in 1990 [6] showed fiber accumulation in the quencher, although smaller in diameter (see Figure 3). It is postulated that the fibers seen in Figure 4 are the result of strands of glass that have been ejected from the melt pool (due to bubbler operations) and collected in the off-gas.
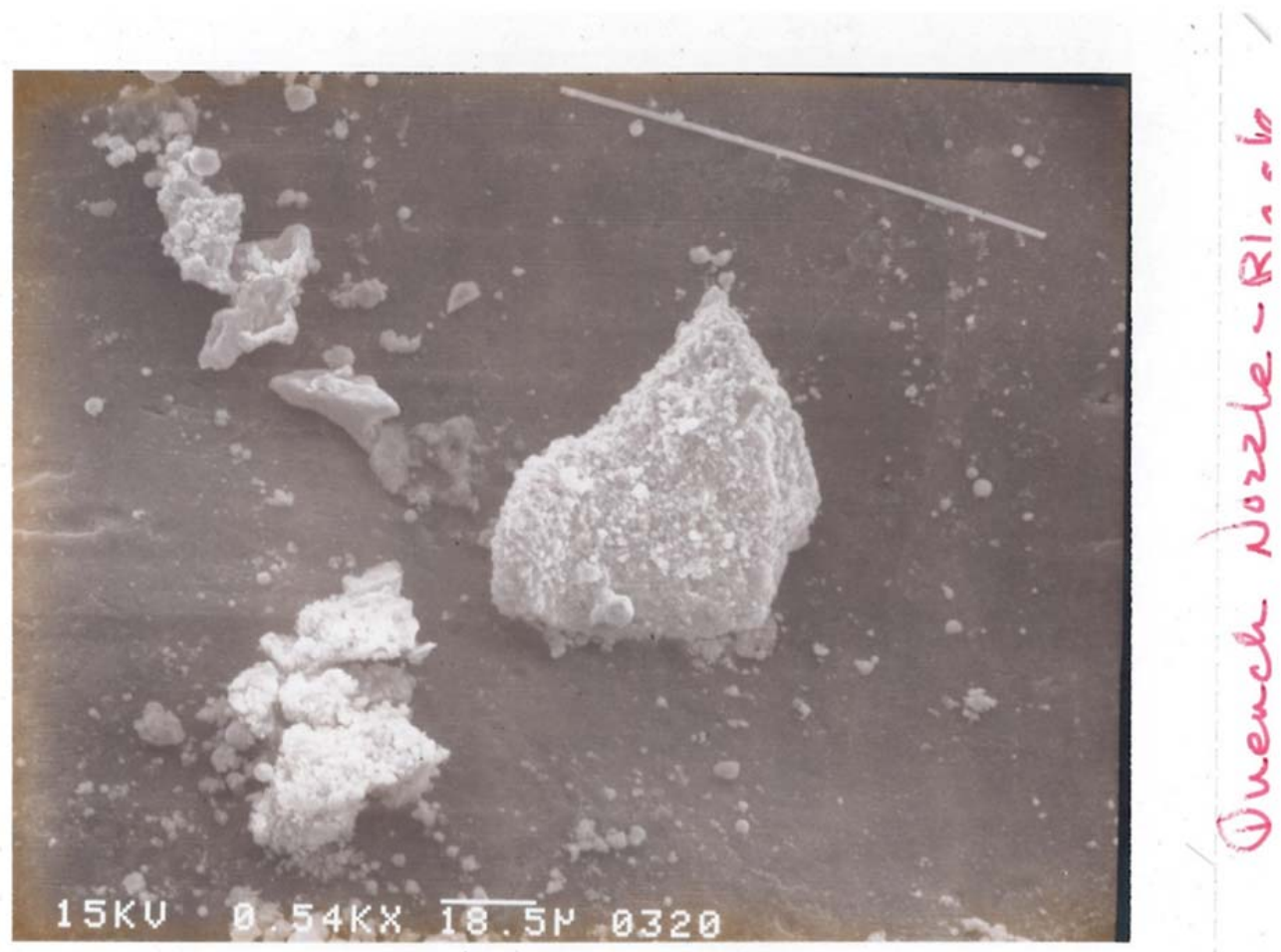

Figure 3: SEM Micrograph of Sample Taken from the Quencher Nozzle in 1990 showing Rod-like Fiber. 


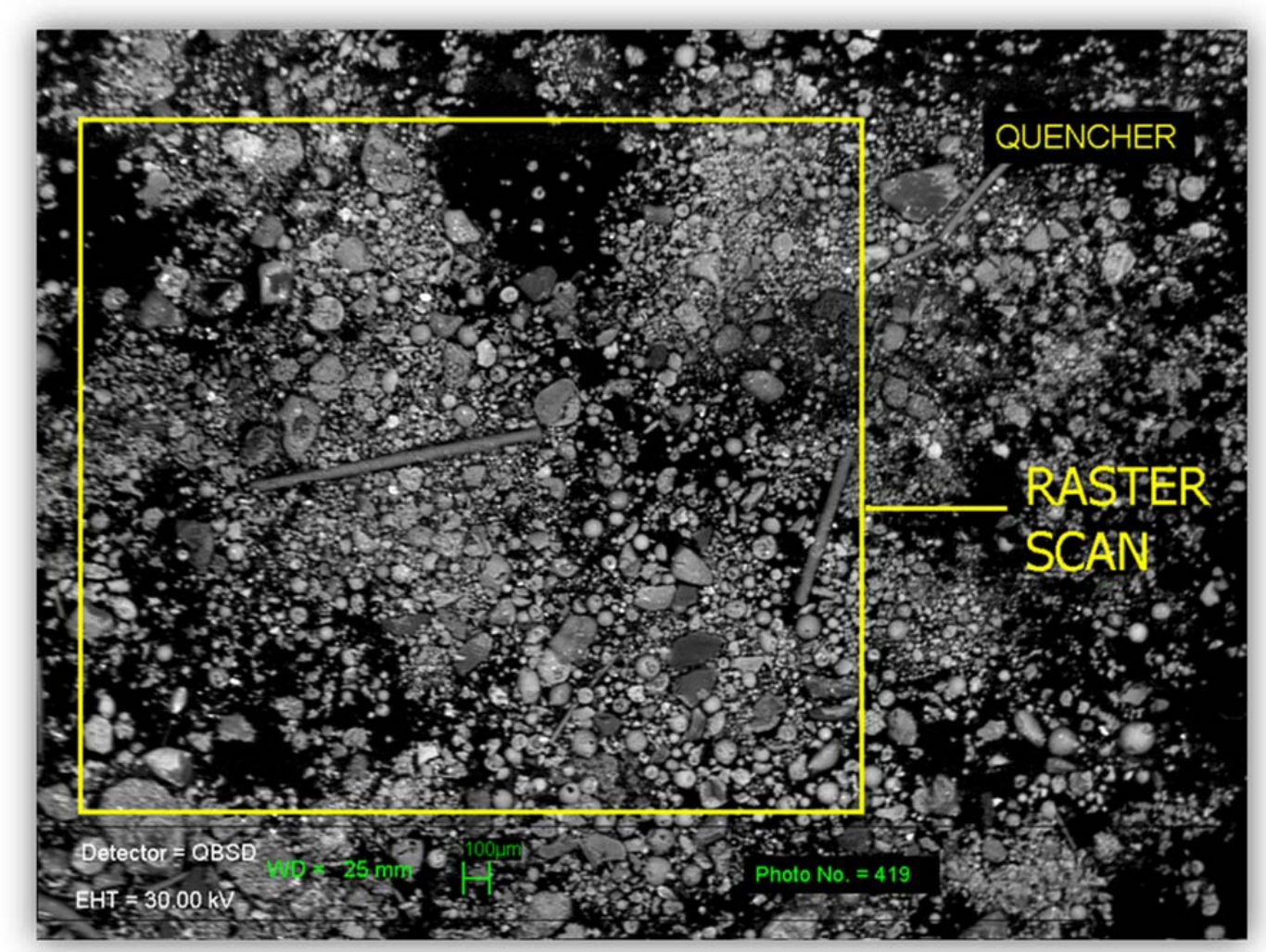

Figure 4: SEM Raster Scan of Bulk Quencher Sample

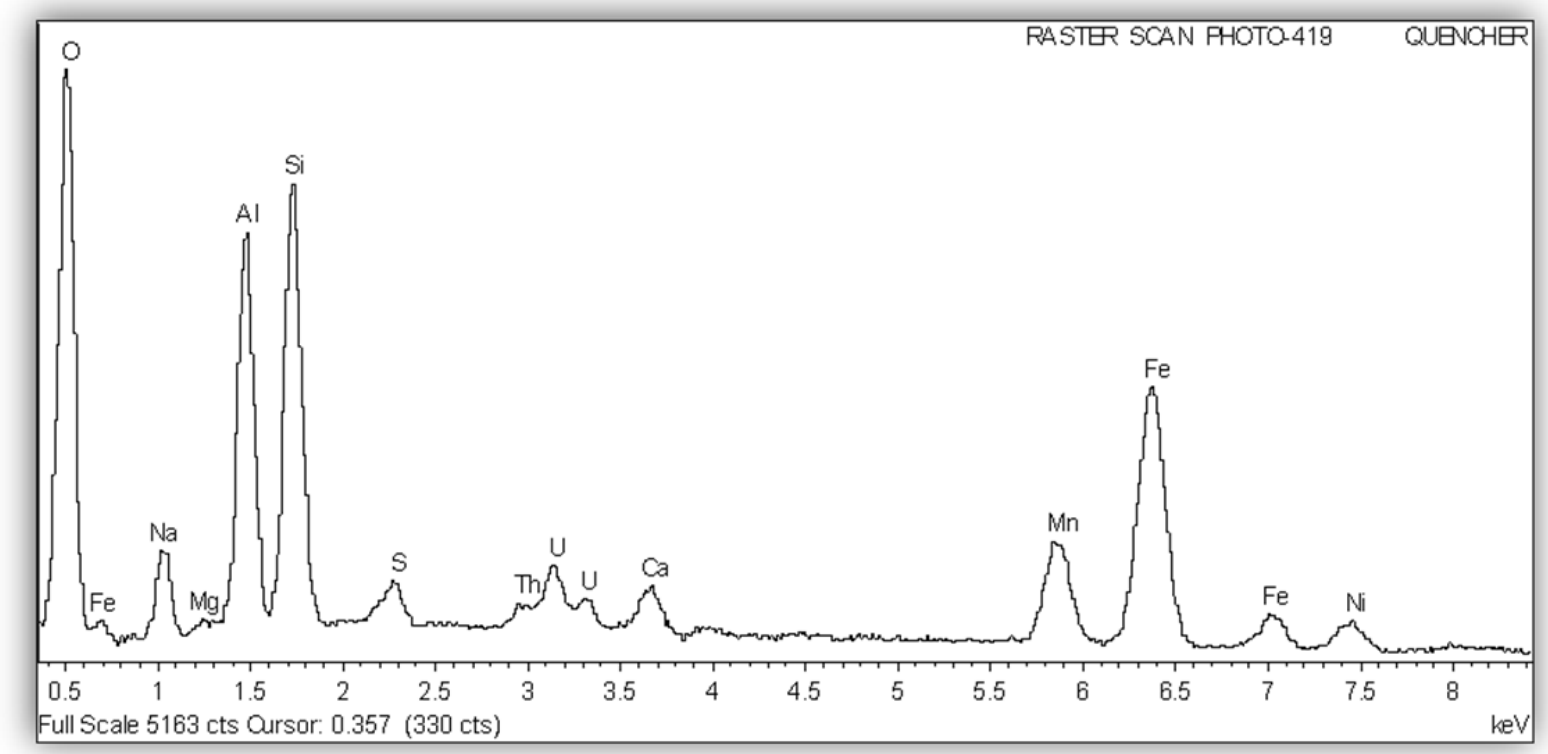

Figure 5: EDX Results of Figure 4 Raster Scan 


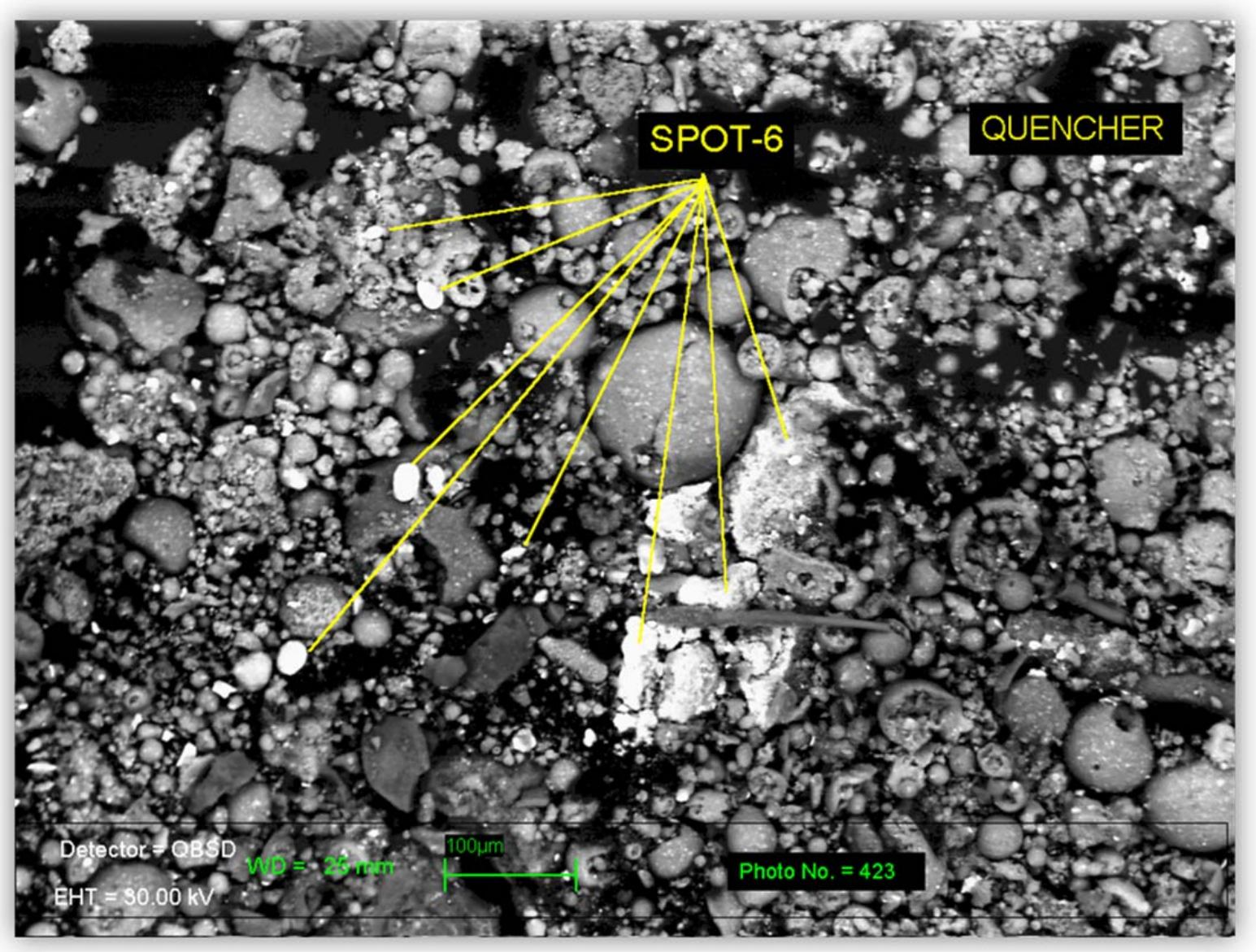

Figure 6: SEM of Quencher Sample

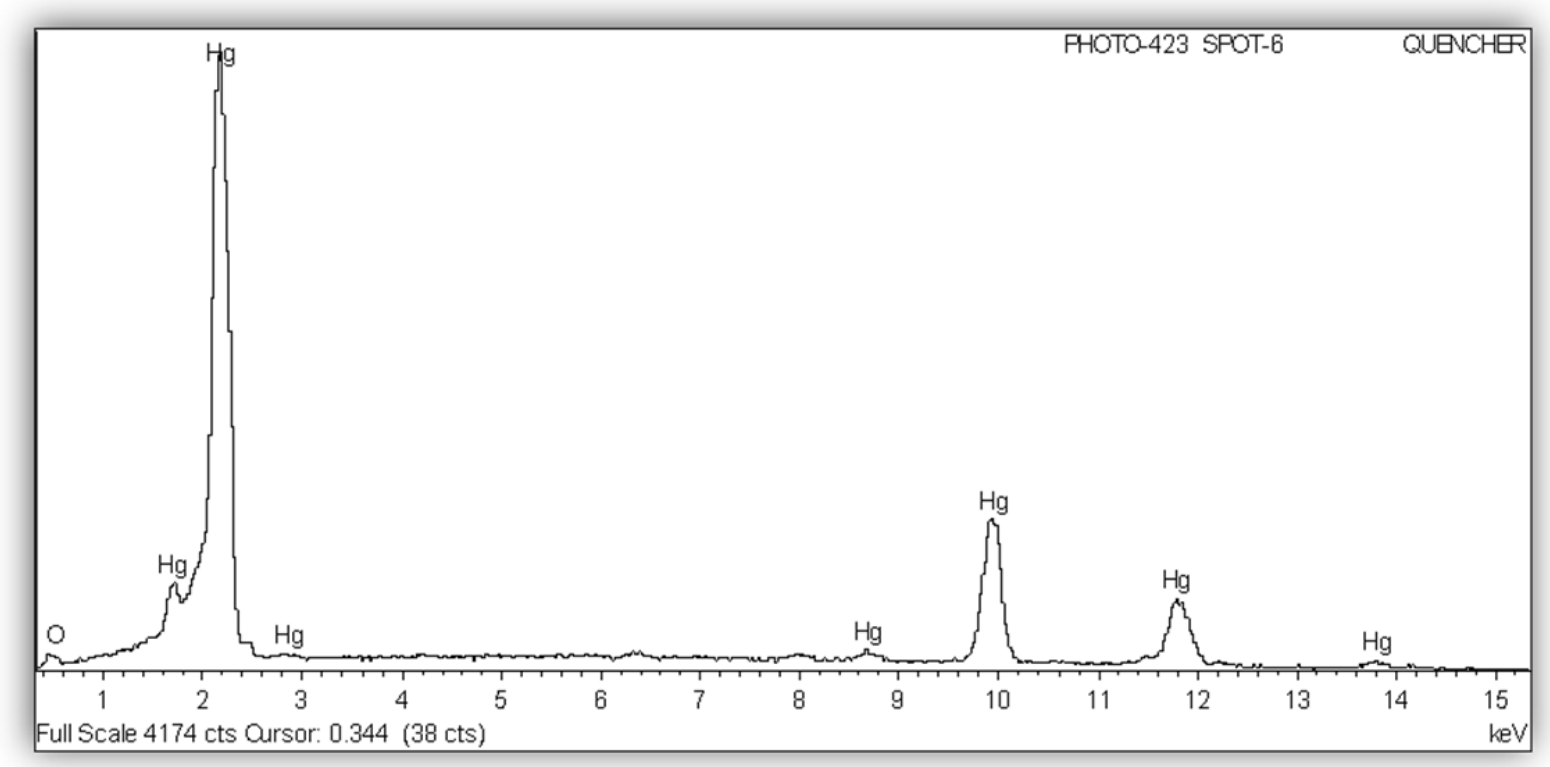

Figure 7: EDX Results of Figure 6 


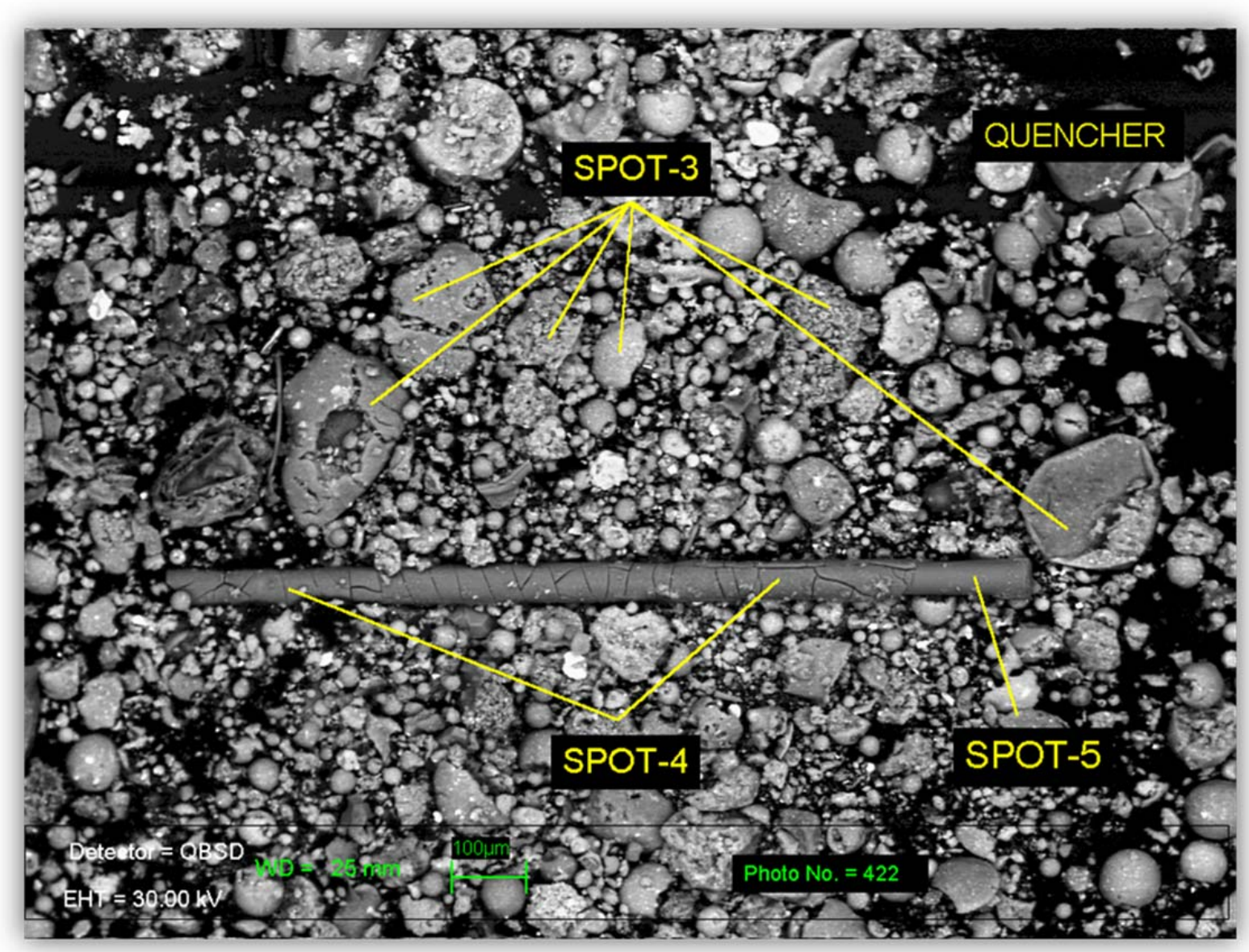

Figure 8: SEM of Quencher Sample

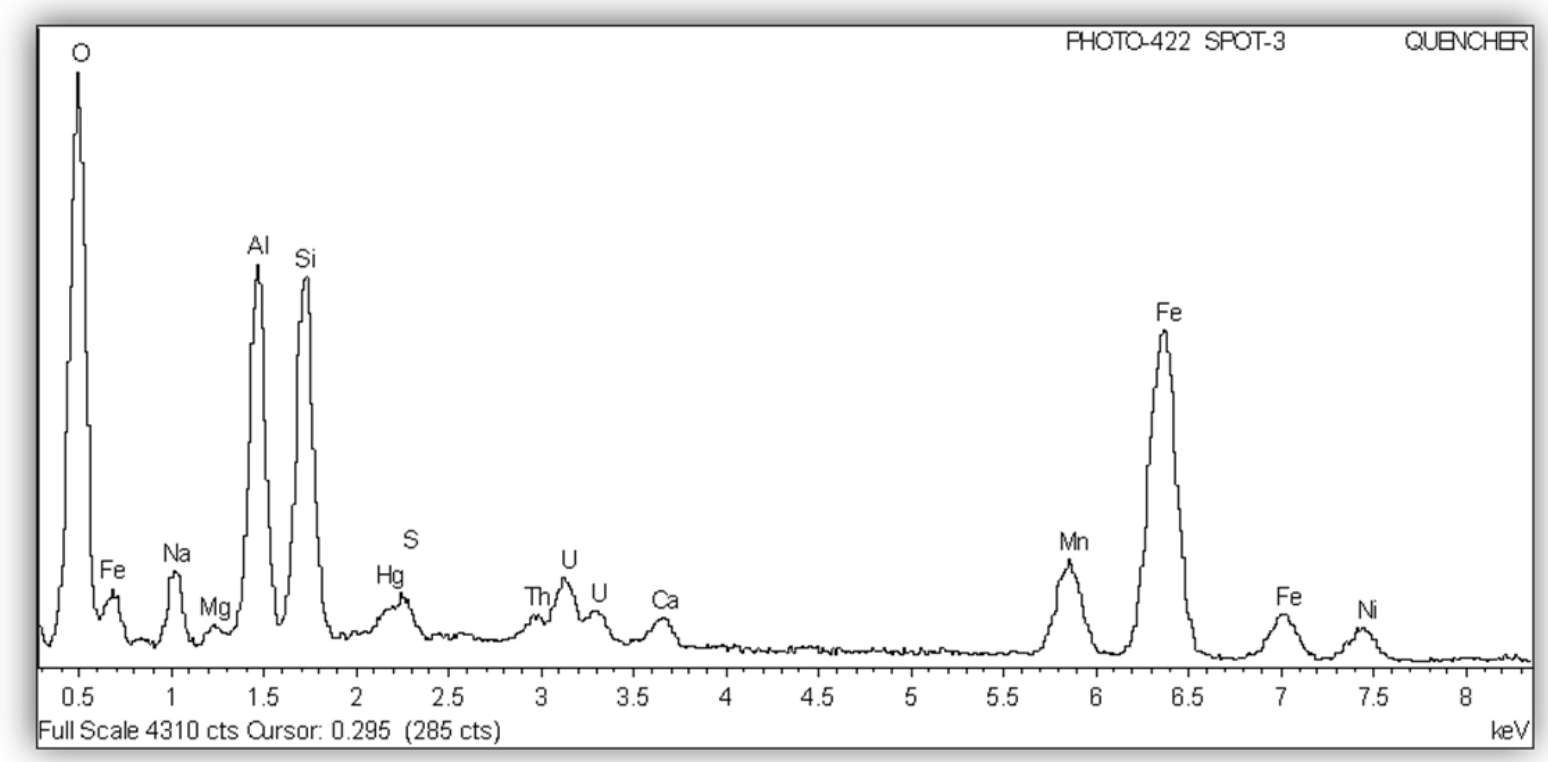

Figure 9: EDX Results of Figure 8, spot 3 


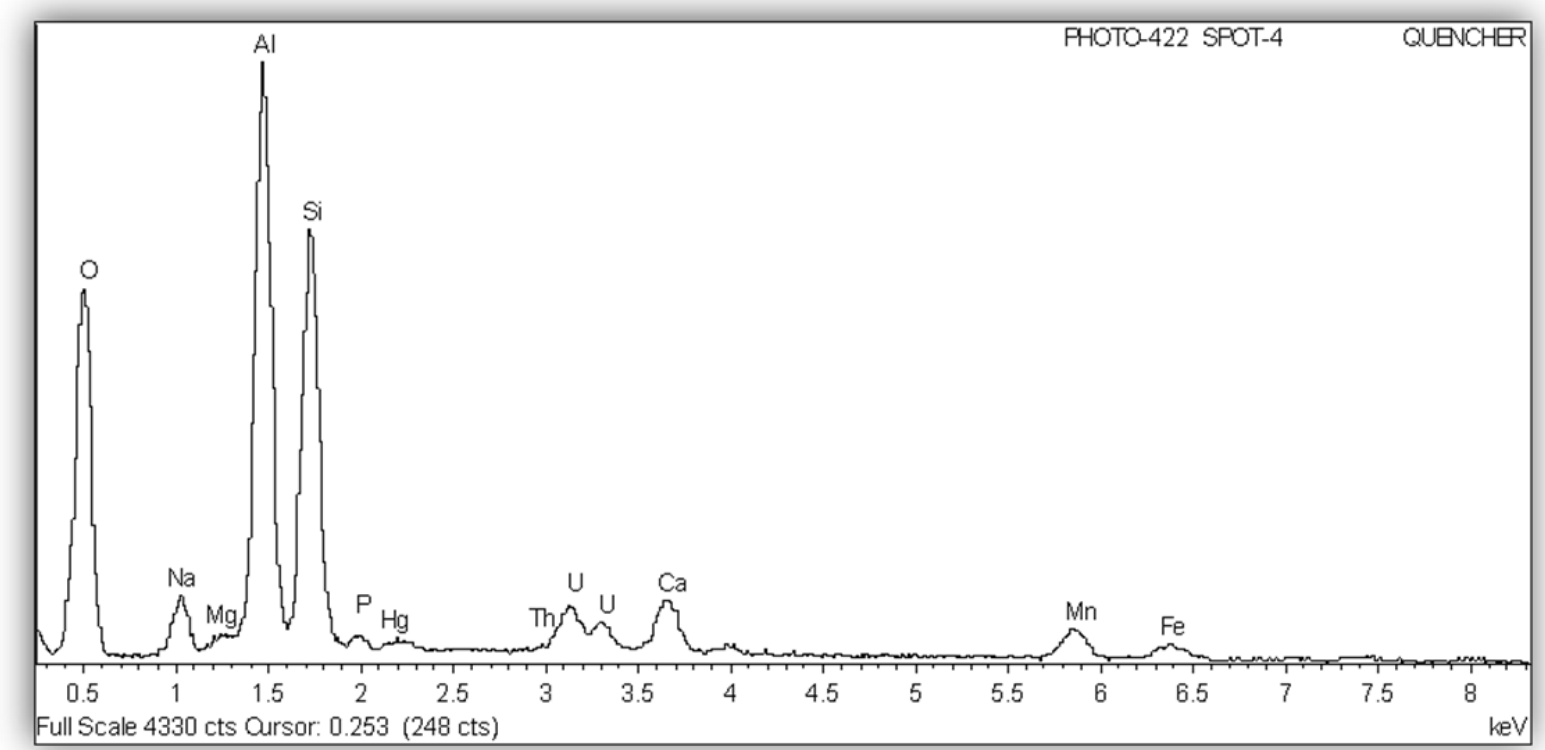

Figure 10: EDX Results of Figure 8, spot 4

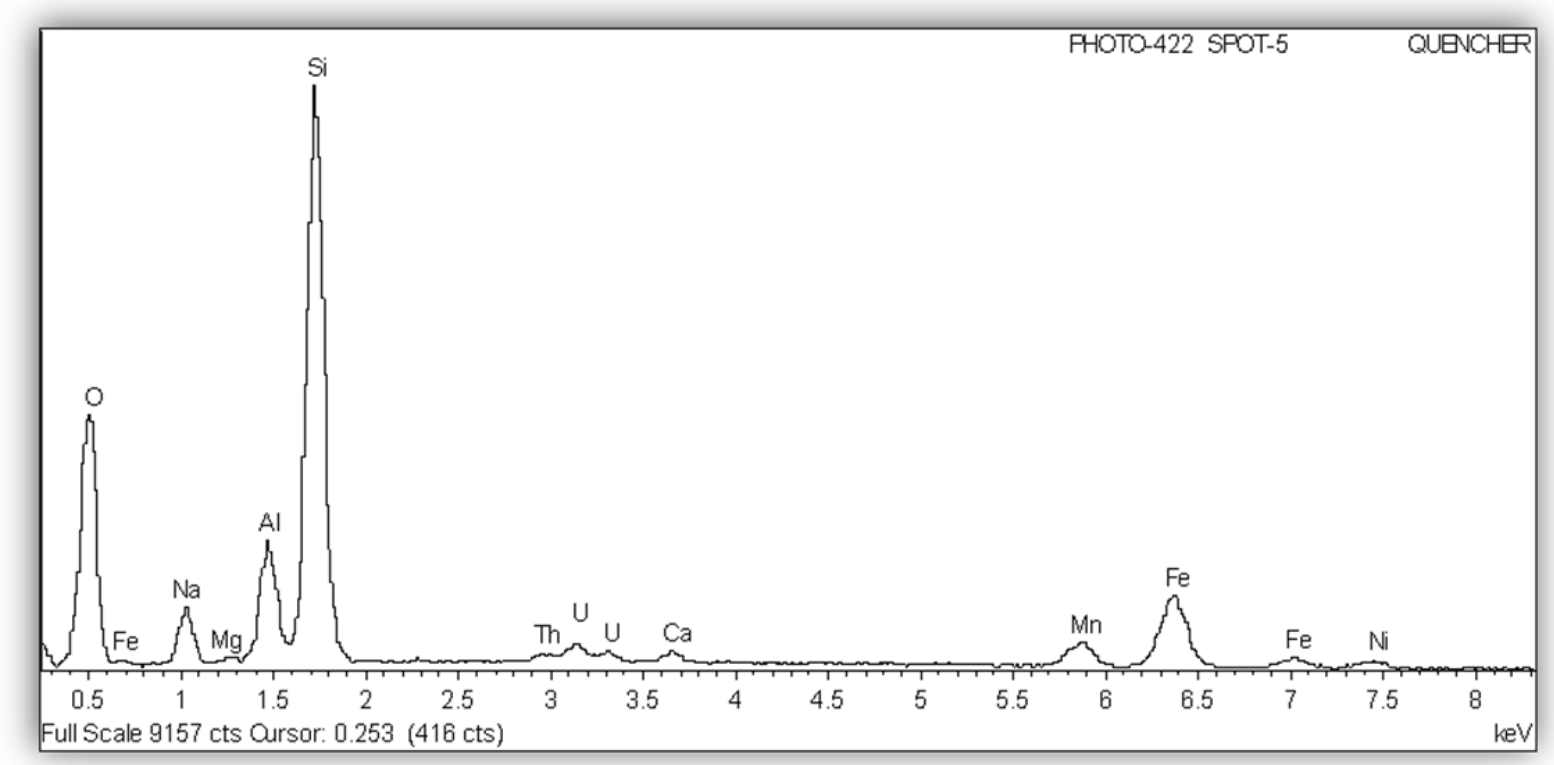

Figure 11: EDX Results of Figure 8, spot 5

\subsection{Elemental Analysis}

Compositional results of the quencher sample are presented in Table 1. The elemental concentrations are given in weight percent for a single sample analyzed in triplicate. The triplicate runs were averaged and the percent relative standard deviation (\%RSD) calculated. The following results are based upon a total solids determination of $54.03 \%$. 
Table 1: ICP-AES Data for Quencher Sample (Total Solids wt\%)

\begin{tabular}{|c|c|c|c|c|c|}
\hline Element & $\begin{array}{c}\text { Quencher- } \\
1\end{array}$ & $\begin{array}{c}\text { Quencher- } \\
2\end{array}$ & $\begin{array}{c}\text { Quencher- } \\
3\end{array}$ & Average & \%RSD \\
\hline Al & 12.88 & 13.18 & 12.81 & 12.98 & 1 \\
\hline B & 0.49 & 0.46 & 0.60 & 0.50 & 9 \\
\hline Ba & 0.12 & 0.13 & 0.12 & 0.12 & 1 \\
\hline Ca & 1.26 & 1.28 & 1.23 & 1.26 & 2 \\
\hline Cd & 0.48 & 0.51 & 0.47 & 0.49 & 3 \\
\hline Ce & 0.09 & 0.09 & 0.09 & 0.09 & 1 \\
\hline $\mathrm{Cr}$ & 0.06 & 0.08 & 0.06 & 0.07 & 11 \\
\hline $\mathrm{Cu}$ & 0.05 & 0.05 & 0.05 & 0.05 & 6 \\
\hline $\mathbf{F e}$ & 12.18 & 12.40 & 12.09 & 12.30 & 1 \\
\hline Gd & 0.09 & 0.09 & 0.09 & 0.09 & 1 \\
\hline $\mathrm{Hg}$ & 2.37 & 2.46 & 2.22 & 2.35 & na \\
\hline $\mathbf{K}$ & 0.05 & 0.05 & 0.05 & 0.05 & 3 \\
\hline La & 0.08 & 0.08 & 0.08 & 0.08 & 4 \\
\hline $\mathbf{L i}$ & 0.88 & 0.83 & 1.05 & 0.93 & 8 \\
\hline Mg & 0.56 & 0.57 & 0.55 & 0.55 & 2 \\
\hline Mn & 4.26 & 4.31 & 4.18 & 4.28 & 1 \\
\hline $\mathrm{Na}$ & 6.77 & 6.42 & 7.44 & 6.88 & 8 \\
\hline $\mathrm{Ni}$ & 1.73 & 1.76 & 1.71 & 1.76 & 2 \\
\hline $\mathbf{P}$ & 0.28 & 0.28 & 0.30 & 0.29 & 4 \\
\hline $\mathbf{P b}$ & 0.03 & 0.03 & 0.03 & 0.03 & 4 \\
\hline $\mathrm{S}$ & 1.06 & 1.03 & 1.02 & 1.04 & 2 \\
\hline Si & 13.23 & 13.40 & 13.64 & 13.42 & 2 \\
\hline $\mathrm{Sr}$ & 0.07 & 0.07 & 0.07 & 0.07 & 5 \\
\hline Th & 1.84 & 1.85 & 1.82 & 1.84 & 1 \\
\hline $\mathbf{T i}$ & 0.25 & 0.24 & 0.25 & 0.25 & 1 \\
\hline $\mathbf{U}$ & 3.70 & 3.83 & 3.68 & 3.54 & 7 \\
\hline Zn & 0.05 & 0.05 & 0.05 & 0.05 & 6 \\
\hline $\mathrm{Zr}$ & 0.22 & 0.21 & 0.26 & 0.23 & 13 \\
\hline
\end{tabular}


Quencher sample ICP-EA data was compared to the SB6 Melter Feed Tank (MFT) sample data. If any of the melter feed was exiting the melter through the off-gas, it could be compositionally similar to that feed being melted. The data in Table 2 would indicate that, for the most part, the quencher sample is compositionally similar to the melter feed. The main exceptions would be those components that make up the frit composition, i.e. silica, boron, lithium, and sodium. The quencher sample appears to be sludge and mercury rich while frit deficient.

Table 2: Comparison of SB6 Melter Feed Tank with the Quencher Sample (Total Solids wt \%)

\begin{tabular}{|c|c|c|}
\hline Element & MFT & Quencher \\
\hline $\mathbf{A l}$ & 11.465 & 12.982 \\
\hline $\mathbf{B}$ & 3.290 & 0.503 \\
\hline $\mathbf{C a}$ & 0.854 & 1.257 \\
\hline $\mathbf{C r}$ & 0.068 & 0.067 \\
\hline $\mathbf{C u}$ & 0.058 & 0.052 \\
\hline $\mathbf{F e}$ & 14.288 & 12.302 \\
\hline $\mathbf{L i}$ & 5.072 & 0.927 \\
\hline $\mathbf{M g}$ & 0.524 & 0.551 \\
\hline $\mathbf{M n}$ & 4.329 & 4.285 \\
\hline $\mathbf{N a}$ & 23.847 & 6.879 \\
\hline $\mathbf{N i}$ & 2.092 & 1.757 \\
\hline $\mathbf{S i}$ & 48.915 & 13.425 \\
\hline $\mathbf{T h}$ & 2.422 & 1.838 \\
\hline $\mathbf{T i}$ & 0.621 & 0.248 \\
\hline $\mathbf{U}$ & 3.714 & 3.535 \\
\hline $\mathbf{Z r}$ & 0.288 & 0.229 \\
\hline
\end{tabular}

Table 3 and Table 4 present the concentration of radionuclides as determined by ICP-MS and gamma counting, respectively. 
SRNL-STI-2011-00520

Revision 0

Table 3: ICP-MS Results of the Quencher Sample

\begin{tabular}{|l|c|c|}
\hline Element & $\begin{array}{c}\text { Average } \\
\text { (wt\%) }\end{array}$ & \%RSD \\
\hline Tc-99 & $4.41 \mathrm{E}-03$ & 8 \\
\hline Ru-101 & $4.80 \mathrm{E}-02$ & 2 \\
\hline Ru-102 & $4.45 \mathrm{E}-02$ & 3 \\
\hline Rh-103 & $1.07 \mathrm{E}-02$ & 4 \\
\hline Rh-104 & $2.61 \mathrm{E}-02$ & 3 \\
\hline Pd-105 & $1.79 \mathrm{E}-03$ & 12 \\
\hline Th-232 & $1.83 \mathrm{E}+00$ & 2 \\
\hline U-234 & $9.56 \mathrm{E}-04$ & NA \\
\hline U-235 & $2.74 \mathrm{E}-02$ & 3 \\
\hline U-236 & $1.68 \mathrm{E}-03$ & 8 \\
\hline U-238 & $3.79 \mathrm{E}+00$ & 2 \\
\hline Pu-239 & $2.09 \mathrm{E}-02$ & 4 \\
\hline Pu-240 & $2.31 \mathrm{E}-03$ & 10 \\
\hline
\end{tabular}

Table 4: Radionuclide Results of the Quencher Sample

\begin{tabular}{|l|c|c|}
\hline Element & Average (uci/g) & \%RSD \\
\hline Co-60 & $9.62 \mathrm{E}-01$ & 1.2 \\
\hline Cs-137 & $1.43 \mathrm{E}+03$ & 4.3 \\
\hline Eu-154 & $1.22 \mathrm{E}+01$ & 2.3 \\
\hline Am-241 & $1.81 \mathrm{E}+01$ & 3.7 \\
\hline
\end{tabular}

3.4 Water Leach of Quencher Sample

Off-gas deposit samples were leached with water at ambient temperature to determine the fraction of water soluble elements present. The triplicate samples were leached for approximately 3.5 days with intermittent shaking. Each solution was sampled and submitted to AD for ICP-ES analysis. Data from Table 5 indicates that half of the boron and sodium and all of the sulfur contained in the quencher sample were water soluble. 
Table 5: Weight Percent of Elements Dissolved in Water from the Quencher Sample

\begin{tabular}{|c|c|c|c|}
\hline Element & $\begin{array}{c}\text { Leached } \\
\text { Sample (g) }\end{array}$ & $\begin{array}{c}\text { Quencher } \\
\text { Sample (g) }\end{array}$ & $\begin{array}{c}\text { Percent } \\
\text { Leached }\end{array}$ \\
\hline $\mathbf{A l}$ & $3.24 \mathrm{E}-05$ & $4.03 \mathrm{E}-02$ & $0.08 \%$ \\
\hline $\mathbf{B}$ & $7.77 \mathrm{E}-04$ & $1.56 \mathrm{E}-03$ & $50 \%$ \\
\hline $\mathbf{C a}$ & $3.34 \mathrm{E}-05$ & $3.90 \mathrm{E}-03$ & $0.86 \%$ \\
\hline $\mathbf{L i}$ & $3.46 \mathrm{E}-04$ & $2.88 \mathrm{E}-03$ & $12.0 \%$ \\
\hline $\mathbf{M g}$ & $6.70 \mathrm{E}-06$ & $1.71 \mathrm{E}-03$ & $0.39 \%$ \\
\hline $\mathbf{M n}$ & $1.28 \mathrm{E}-06$ & $1.33 \mathrm{E}-02$ & $0.01 \%$ \\
\hline $\mathbf{N a}$ & $9.93 \mathrm{E}-03$ & $2.14 \mathrm{E}-02$ & $46 \%$ \\
\hline $\mathbf{S}$ & $3.94 \mathrm{E}-03$ & $3.22 \mathrm{E}-03$ & $122 \%$ \\
\hline $\mathbf{S i}$ & $6.58 \mathrm{E}-05$ & $4.17 \mathrm{E}-02$ & $0.16 \%$ \\
\hline $\mathbf{S r}$ & $3.80 \mathrm{E}-07$ & $2.06 \mathrm{E}-04$ & $0.18 \%$ \\
\hline total & $1.51 \mathrm{E}-02$ & $1.30 \mathrm{E}-01$ & $12 \%$ \\
\hline
\end{tabular}

\subsection{Conclusions}

Based on the analytical results obtained from the quencher sample, the following conclusions can be made:

- XRD data indicates the sample contained crystalline structures composed of trevorite, hematite, quartz, and ruthenium oxide.

- The off-gas quencher deposit is compositionally similar to mercury enriched, frit deficient SB6 melter feed.

- Morphologically, the deposit sample is not similar to previous samples. Previous samples had clear indication of the presence of frit, which is lacking in the current samples. In addition, observable rod-like fibers can be seen in the SEM micrographs.

- Gamma scans detected emitters Co-60, Cs-137, Eu-154, and Am-234. Of these Cs-137 was in the highest concentration.

- Water leach testing indicated soluble sodium, boron, and sulfur in the quencher sample. $12 \%$ of the total sample was water soluble.

Three possible scenarios could explain the sludge rich/ frit deficient nature of the quencher deposit were identified:

1. Sludge being selectively entrained in the off-gas. As a result of this selectivity, the deposit forming in the quencher is lacking in frit, which can be easily seen in the SEM analyses. This scenario is considered unlikely, as this type of separation has not been seen before, even with non-bubbled operations. While it is understandable that bubbler 
use will increase the amount of melter feed carryover, it would not explain the separation of sludge and feed.

2. The frit in the quencher deposit being selectively leached after depositing. The low $\mathrm{pH}$ of the recirculated off-gas condensate is dissolving the frit fraction of the melter feed. This scenario is also considered unlikely, as silica dissolution in glass occurs at higher $\mathrm{pH}$ rather than lower [7]. As the $\mathrm{pH}$ of the quencher water is approximately $\mathrm{pH}=2$, there would be little dissolution of the frit. It was considered more probable that the sludge would leach from the deposit than the frit.

3. The third scenario identified is that the quencher deposit is a result of particulate that has accumulated in the OGCT and has separated into frit and sludge fractions as the frit settles to the bottom of the OGCT and the sludge particles suspend in the condensate. Sludge particles are entrained in the condensate as it recycles through the quencher and deposits below the melter spout jet. Comparison of the compositional analyses of the quencher and MFT samples reveals the possibility that the quencher deposits are the sludge component of the melter feed.

A high concentration of mercury was found in the quencher deposit (2.35 wt\%) and exists primarily in the elemental oxide form. The presence of mercury in the quencher is likely attributed to increasing the allowable mercury concentration sent to the melter.

SEM analysis of the quencher sample showed the presence of rod-like fibers. These fibers range from a couple of microns in diameter to 50 microns and lengths approaching $1 \mathrm{~mm}$. The fiber structure appears to be composed of an inner rod made mostly of silica with a coating that would be consistent with melter feed composition. In order to determine that the fibers are not the result of refractory collecting in the off-gas, DWPF provided Zircar and Kaowool refractory samples for SEM analysis. The analysis showed these samples to be orders of magnitude smaller in diameter than the fibers seen in the quencher sample. In addition, review of work performed by Jantzen in 1990 [6] showed fiber accumulation in the quencher, although smaller in diameter. It is postulated that the fibers seen are the result of strands of glass that have been ejected from the melt pool (due to bubbler operations) and collected in the off-gas.

\subsection{Recommendations}

In order to confirm the deposits are a result of feed in the OGCT, SRNL recommends DWPF Engineering sample the OGCT for chemical and physical analyses. Confirmation of feed in the condensate would indicate a need for evaluating methods to prevent melter feed from reaching the quencher (i.e. filtration). Samples should be taken from top and bottom of the OGCT before and after agitation.

In order to decrease the agglomeration of material in the quencher, the following recommendations are considered: 1 . OGCT $\mathrm{pH}$ adjustment, 2. Flocculant addition to the OGCT, 3. Periodic cleaning of the OGCT, 4. Addition of a steam or water jet inside the quencher, and 5. Slope angle adjustment of the quencher.

1. Currently, the OGCT $\mathrm{pH}$ is $\sim 2$. Lowering the $\mathrm{pH}$ of a mixture allows for more of the suspended particles to dissolve. In order to dissolve the suspended particles, the resulting acid concentrations (nitric, for example) may need to be as high as 6-8 molar. The amount of acid that would be needed would make this an impractical recommendation. 
2. Flocculation is a process used to increase the efficiency of settling and clarification of a suspension. This is achieved as the flocculant forms bridges between suspended particles and aids in particle aggregation. While the use of a flocculant would benefit a motionless tank, the OGCT is not quiescent. As such, it is not expected that using a flocculating agent would improve the settling rate of suspended sludge particles sufficiently to prevent suspension of the particles. In addition, forcing the particles to settle could result in accumulated deposits in the tank that are difficult to suspend. Furthermore, the flocculating agent could potentially make the accumulation of solids in the quencher more severe.

3. Quencher operation over time results in particulate accumulation of any entrained solids from the off-gas system in the OGCT. Periodic cleaning of the OGCT would not result in cleaner recirculated water and slower rate of deposition in the quencher, as suspended solids are removed during frequent liquid fraction transfers of the OGCT. Cleaning the settled solids will have little or no impact on the amount of material suspended in the tank. The accumulated solids settled on the bottom of the OGCT are not likely to be contributing to the quencher deposits.

4. The deposit recently observed in the quencher was in a position just below the quencher nozzle. The addition of a steam or water jet inside the quencher below the nozzle could be used to dislodge the deposit as it forms. Visual observation by DWPF personnel of the deposit during sample collection showed it to be a friable material; however, this may not be consistent with future sludge batches.

5. Currently, the quencher is positioned so as to slope downward at an angle of 20 degrees from horizontal. Increasing the downward slope of the quencher, even to 90 degrees downward from horizontal, could help with controlling the deposition of material. 


\subsection{References}

1. J.P. Windham and E.W. Holtzscheiter, "Melter Off Gas System," HLW-DWPF-20100008, 2011.

2. $\quad$ "Defense Waste Processing Overview, Facility Systems Training Study Guide," W5BC200XSTGD000104, Rev. 4, January 2007.

3. N.E. Bibler, "Characterization of Three Samples Taken from the Off-gas System of DWPF Melter One," WSRC-TR-2003-00423, 2003.

4. C.M. Jantzen, "Glass Melter Off-Gas System Pluggages: Cause, Significance, and Remediation," Savannah River Site, Aiken, SC, WSRC-TR-90-205.

5. $\quad$ K.E. Zeigler and N.E. Bibler, "Characterization of DWPF Melter Off-gas Quencher and Steam Atomized Scrubber Deposit Samples," Savannah River Natioal Laboratory, Aiken, SC, WSRC-STI-2007-00262.

6. $\quad$ C.M. Jantzen, "Melter Off-gas Deposits," WSRC-NB-90-391.

7. B.P. McGrail, W.L. Ebert, A.J. Bakel, and D.K. Peeler, "Measurement of Kinetic Rate Law Parameters on a Na-Ca-Al Borosilicate Glass for Low-Activity Waste," Journal of Nuclear Materials, 249 175-89 (1997). 


\section{Distribution:}

J.W. Amoroso, 999-W

A.B. Barnes, 999-W

D.R. Best, 999-W

J.M. Bricker, 704-27S

T.L. Fellinger, 704-26S

S.D. Fink, 773-A

K.M. Fox, 999-W

C.C. Herman, 999-W

E.W. Holtzscheiter, 704-15S

J.F. Iaukea, 704-30S

P.R. Jackson, 703-46A

F.C. Johnson, 999-W

D.C. Koopman, 999-W
D.P. Lambert, 999-W

S.L. Marra, 773-A

J.D. Newell, 999-W

J.E. Occhipinti, 704-S

D.K. Peeler, 999-W

F.M. Pennebaker, 773-42A

H.M. Pittman, 704-27S

J.W. Ray, 704-S

D.C. Sherburne, 704-S

M.E. Smith, 704-30S

A.V. Staub, 704-27S

M.E. Stone, 999-W

J.P. Windham, 704-30S

J.R. Zamecnik, 999-W 